\title{
Conflict in collective forest tenure: Lessons for Peru from a comparative study
}

\author{
Anne M Larson, lliana Monterroso and Nicole Heise Vigil
}

\section{Key messages}

- In comparison with Indonesia, Uganda and Nepal, Peruvian law provides a weak mandate for tenure reform implementers to address conflict, and Peru has the lowest number of implementing officials stating that addressing conflict is among their responsibilities.

- In the villages studied, Peru reports the highest proportion of villagers involved in land or forest conflicts, the highest proportion with actors external to the community and the lowest portion resolved.

- Despite the legal significance of a land title, collective titling alone does not assure the end of land/forest disputes with outsiders. The state needs to defend the property rights that it has recognized.

- Peru must improve its legal framework for conflict management in land/forest disputes both in and after formalization processes, drawing on state and customary, community or alternative mechanisms.

\section{Introduction}

Land and forest tenure reforms for customary and other forest dependent peoples have been implemented, among other things, to reduce conflict over land and resources. But reforms themselves can cause new conflicts, for example, due to exclusion of members, changes in boundaries and contradictions with customary laws (see Coldham 2000; Fitzpatrick 2005; Gautam et al. 2014). Further, titling does not necessarily stop competition for land or resources. This article focuses specifically on collective tenure reforms in forests and forest lands. Here, reforms refer to formalization processes that range from collective titling (in Peru) to social forestry, community forestry or collaborative forestry regimes (in Indonesia and Uganda). The full dataset referenced is complex, the reforms and contexts are varied, and conclusions nuanced; however, the results point to striking lessons for Peru, reinforcing our observations from the broader research project and suggesting important policy recommendations.

This brief compares the perspectives of government officials in charge of implementing reforms (in Peru, Nepal, Indonesia and Uganda) with those of communities that have undergone reforms (in Peru, Indonesia and Uganda). It examines the role of government in conflict management, the nature of conflict and conflict resolution. The research did not use a pre-determined definition but rather aimed to understand perceptions of conflict in relation to collective tenure regimes as they emerged from interviews with different actors. Respondents referred to different types of conflict in part based on the nature and scale of the question, which is important for interpreting results and proposing solutions. This brief explores the nature and extent of government responsibility for addressing conflict in collective tenure regimes.

The comparative results presented here challenge the idea that a property title is a secure form of land tenure, or that titling represents the end point in a process of securing rights. In Peru, much greater attention is needed for conflict resolution or transformation in collective tenure regimes, through both government and customary or alternative dispute resolution institutions.

\section{Methods}

This research uses data from a multi-actor, multi-method comparative study on forest tenure reforms undertaken in seven countries by CIFOR from 2014 to 2017.' The brief draws on secondary data to examine laws addressing the role of government in conflict management and on

\footnotetext{
1 The other countries are: Colombia, Democratic Republic of Congo and Kenya. The village-level research was only conducted in Indonesia, Peru and Uganda. The implementers survey was conducted in these three countries plus Nepal and Kenya, but the Kenya results were not available at the time of this analysis.
} 
Table 1. Tenure regimes included in this analysis

\begin{tabular}{|c|c|c|c|}
\hline \multirow{2}{*}{ Tenure regimes } & \multicolumn{3}{|c|}{ Reform Type (\# of communities) } \\
\hline & Uganda & Indonesia & Peru \\
\hline \multirow{2}{*}{$\begin{array}{l}\text { State land designated for use by } \\
\text { communities }\end{array}$} & \multirow{2}{*}{$\begin{array}{l}\text { Collaborative forest } \\
\text { management }(n=4)\end{array}$} & $\begin{array}{l}H K m^{*} \text { (community forest) } \\
(n=5)\end{array}$ & \multirow{2}{*}{-} \\
\hline & & $\begin{array}{l}\mathrm{HTR}^{* *} \text { (community plantation } \\
\text { forest) }(n=2)\end{array}$ & \\
\hline State land used by companies & - & $\begin{array}{l}\text { Kemitraan (partnership) } \\
(n=4)\end{array}$ & - \\
\hline \multirow{2}{*}{ Land owned by communities } & \multirow{2}{*}{ Community forest $(n=4)$} & \multirow{2}{*}{$\begin{array}{l}\text { Hutan Adat (customary } \\
\text { forest) }(n=1)\end{array}$} & Native communities titled $(n=17)$ \\
\hline & & & Peasant communities titled $(n=1)$ \\
\hline Land owned by individuals & $\begin{array}{l}\text { Private forest owners' } \\
\text { association }(n=4)\end{array}$ & - & - \\
\hline $\begin{array}{l}\text { Other recognized customary } \\
\text { lands }\end{array}$ & $\begin{array}{l}\text { Customary lands } \\
\text { (multiple reforms) }(n=4)\end{array}$ & - & - \\
\hline Total & 16 & 12 & 18 \\
\hline
\end{tabular}

two main sources of primary data from four of the countries. First, 119 interviews were conducted with key government implementers of reforms from Peru (32), Uganda (30), Nepal (29) and Indonesia (28). These individuals were selected according to the mapping of specific, required implementation steps and thus represent the most important officials involved. Government respondents were asked about their responsibility for managing conflict, the types of conflicts they are called on to manage and whether resolution mechanisms are effective.

The second dataset is from village level. Research included 55 communities, in Peru (22), Uganda (16) and Indonesia (17), representing different types of reforms as well as a small number of customary (non-reformed) communities. The full dataset includes 2,075 household survey interviews, conducted separately with men and women. A total of 136 key informant interviews and 164 focus groups were also separately conducted with men and women. Some residents of villages in Indonesia and Uganda did not participate in reforms. We excluded non-reformed villages and non-participants in reformed villages from the analysis in this brief, in order to compare only reform participants. In sum, the survey analysis here includes 835 people in Peru, 522 in Indonesia and 249 in Uganda. ${ }^{2}$ They were asked if they had been involved in conflict in the previous year, the source of conflict, who it was with, whether it was resolved and, if so, who resolved it. At village level, key informants and focus groups were asked to explain conflicts both internally and with outsiders (e.g. companies, government, neighboring villages), as well as the relationship of conflicts to tenure reforms.

The types of reforms studied (see Table 1) vary widely and are grouped by "regime type" based primarily on three of four

2 Some results from Peru's four non-reformed (untitled) villages (171 respondents) are included to enrich the Peru analysis where useful. categories used by the Rights and Resources Initiative (RRI 2018): state land designated for community use, land owned by communities and land owned by individuals. The sample includes one additional category only seen in Indonesia: state land designated for the use of companies (the company negotiates land rights with villagers). It includes only one site with individual private lands (in Uganda); and one site where at least two different reforms had been undertaken in what we had originally thought were customary villages without reforms (in Uganda). For the purposes of this brief, the results are aggregated by country, but they should not be taken to represent country-level findings. Rather, they are useful for extracting patterns - particularly lessons for Peru - and also for comparison with government responses.

\section{Responsibility in conflict management}

In the four countries, national laws vary in the degree of responsibility for conflict management given to tenure reform implementers and in the provision of community-based mechanisms. Peru appears to have the weakest government mandate. Uganda is the only country that mandates a clear community-based mechanism for tenure conflict resolution.

In Peru, a 2002 Decentralization Law (Law no. 27867) moved the responsibility for land titling to regional governments. The law does not mention conflict management, however, nor do laws on native community titling. If community lands are located in protected areas, protected area legislation (Art. 15 of Supreme Decree AG N038/2001) mandates the area's Management Committee to resolve disputes. In terms of community-based conflict resolution mechanisms, the 1993 Constitution recognizes the jurisdiction of indigenous communities over their territories in accordance with customary laws (as long as the fundamental rights of a person 
are not violated), and the 1974 Law of Native Communities (22175, Art. 19) allows community resolution of minor civil disputes. Overall, however, land titling processes do not include a specific mandate on conflict management, and what does exist appears to be dispersed among different government institutions without clear guidelines.

In contrast, Indonesian laws explicitly acknowledge the existence of conflict in land-tenure formalization processes, and mandates are clearer. The Forest Law (Art. 74-76) specifically addresses the settlement of forest disputes and notes that these "can be settled intra- or extra-judicially based on voluntary option of the disputing parties" (Art. 74), though this does not apply for criminal acts (RRI, 2017). The National Land Agency (BPN), now integrated with the Ministry of Agrarian and Spatial Planning, is responsible for land-tenure conflict management, and national laws outline responsibility for provincial, cross-provincial and cross-district conflict resolution (Ardiansyan et al. 2015). In this regard, Indonesian law provides a clear mandate for government to address conflict and for alternative (extra-judicial) mechanisms, although it does not specify a community-based mechanism.

Uganda also clearly acknowledges conflict, and the mandate for conflict resolution is given to a variety of entities: "There are currently 5 different land disputes resolution mechanisms (...) set up under the 1998 Land Act in an effort to bring land services closer and more acceptable to the users" (Uganda Land Alliance, 2014, p.185). The Local Council Courts (LCCs) are the lowest level of formally recognized courts in Uganda and can enforce customary or traditional laws, based on the Constitution (Art. 129, 1995) and the Local Council Court Act. LCCs operate as a first instance mechanism for most disputes, including land disputes, and they are affordable. Additionally, the Land Act recognizes customary procedures for land dispute settlement (Art. 5). This approach makes alternative and traditional conflict resolution mechanisms available, although it has also been criticized for generating confusion and "resulting in backlogs of unresolved cases" (Uganda Land Alliance, 2014, p. 185).

In Nepal, the Forest Act acknowledges conflicts that can arise from boundary demarcation (by the District Forest Office) and establishes clear procedures for complaints (Art. 5-10). The District Forest Office manages this; however, committee members may lack the necessary skills (Shrestha, 1998). The Forest Act authorizes Forest User Groups (FUGs) to resolve local conflicts to a certain extent, as it allows them to "impose an appropriate punishment" (Art. 29) when the community forest work plan is violated. The authorization for FUGs "has often created confusion in resolving tenure conflict as no further guideline is provided" (Yasmi et al. 2016). In addition, Heinen and Mehta (2000) argue that there are problems articulating responsibilities between different government institutions.

As part of the research, reform implementers were asked whether they or their office was responsible for managing or resolving tenure-related conflicts. Overall, half stated "yes", that they are responsible, but with substantial differences between countries (see Figure 1). In Peru, only 28\% said yes. It is somewhat surprising that Indonesia and Uganda are not higher, given their legal mandates; however, this may be because the clearer mandates are around land, and most of the reforms studied involve forest reforms. Nepal provides a substantial contrast.

\section{Is it the responsibility of you or your office to manage or resolve tenure-related conflicts?}

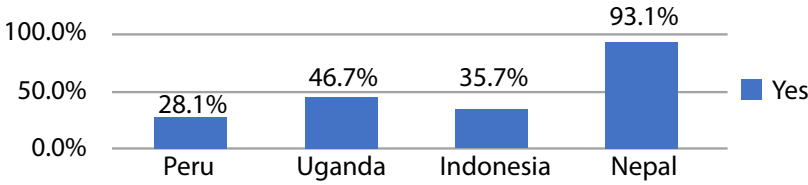

Figure 1. Government implementers' perception of their responsibility for conflict management

\section{Villagers involved in conflict}

Village survey respondents were asked ${ }^{3}$ if they had been involved in a forest or land conflict during the previous year (see Figure 2). Higher levels of conflict were found in Peru and Uganda (about 20\%), compared to only 4\% in Indonesia, and this difference is significant $(p<0.0001) .{ }^{4}$ In non-reformed villages in Peru (not shown in the graph), only 9\% people were involved in conflict. Although Peru has one of the highest levels of conflict at the village level, it has the lowest proportion of reform implementers responsible for conflict resolution.

Have you been involved in a land/forest-related conflict during the year?

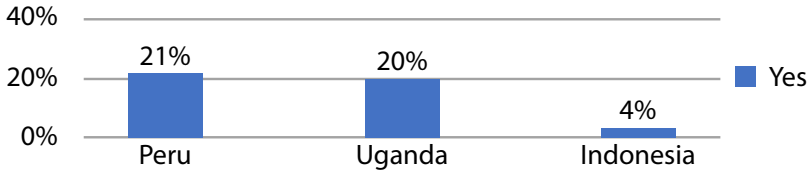

Figure 2. Village respondents involved in a land- or forestrelated conflict in the previous year

\section{Types of conflicts implementers are called to address}

Reform implementers who responded that addressing conflict is their responsibility were asked to describe the main types of tenure-related conflicts that they are called to manage or resolve. Responses were open-ended and then later coded by the research team (see Table 2 ).

3 Nepal is excluded because data was not collected at village level.

4 Differences are significant according to Pearson chi-squared test. All statistical tests were performed at a confidence level of 95\%. 
Table 2. Main tenure-related conflicts implementers have been called to manage or resolve by country

\begin{tabular}{|c|c|c|c|c|}
\hline Type of conflict & Indonesia & Nepal & Peru & Uganda \\
\hline Forest management group or community governance & $0 \%$ & $32 \%$ & $20 \%$ & $26 \%$ \\
\hline Unclear/overlapping land boundaries & $31 \%$ & $8 \%$ & $12 \%$ & $18 \%$ \\
\hline $\begin{array}{l}\text { Government institutional weakness or lack of resources (no mention of law } \\
\text { enforcement) }\end{array}$ & $8 \%$ & $6 \%$ & $28 \%$ & $4 \%$ \\
\hline Concessions and private company activity & $27 \%$ & $0 \%$ & $0 \%$ & $4 \%$ \\
\hline Lack of legal regulation or law enforcement & $4 \%$ & $1 \%$ & $16 \%$ & $6 \%$ \\
\hline $\begin{array}{l}\text { Restriction to local subsistence or economic activities by land use or } \\
\text { conservation policies }\end{array}$ & $15 \%$ & $6 \%$ & $0 \%$ & $14 \%$ \\
\hline Unequal natural resources distribution between community members or users & $0 \%$ & $13 \%$ & $0 \%$ & $2 \%$ \\
\hline Encroachment/land invasion & $4 \%$ & $4 \%$ & $0 \%$ & $10 \%$ \\
\hline Illegal logging, harvesting, poaching or other natural resource extraction & $4 \%$ & $7 \%$ & $8 \%$ & $6 \%$ \\
\hline Wildlife attacks or natural disasters & $0 \%$ & $8 \%$ & $0 \%$ & $4 \%$ \\
\hline Other & $8 \%$ & $16 \%$ & $16 \%$ & $6 \%$ \\
\hline
\end{tabular}

The commonest responses in Nepal and Uganda, second in Peru, related to internal forest management group or community governance problems. ${ }^{5}$ Examples include: lack of agreement, enforcement, budget and transparency, as well as corruption, elite capture, benefit sharing and issues with outsiders. In Peru, the commonest response referred to institutional problems, such as lack of resources, specialized personnel or communication mechanisms; overlapping government functions; and financial transparency. Lack of law enforcement was the third most common answer. In Indonesia, the commonest response was unclear/overlapping land boundaries (second in Uganda), followed closely by concessions and private company activity. Conflict over restrictions on local subsistence activities was the third commonest answer in Uganda and Indonesia, and has been mentioned elsewhere as a problem in Nepal (Shrestha, 1998; Gautam et al. 2004).

\section{Types of conflict from villagers' perspective}

The village members involved in conflict were asked who the conflict was with (see Figure 3). In Indonesia and Uganda, more than half were with other community members. This jumps to three-quarters if family members are added. In contrast, the largest proportion in Peru were conflicts with external actors and less than a third were with community members. Curiously, 20\% declined to answer the question (possibly due to the sensitivity of the issue). In non-reformed villages in Peru,

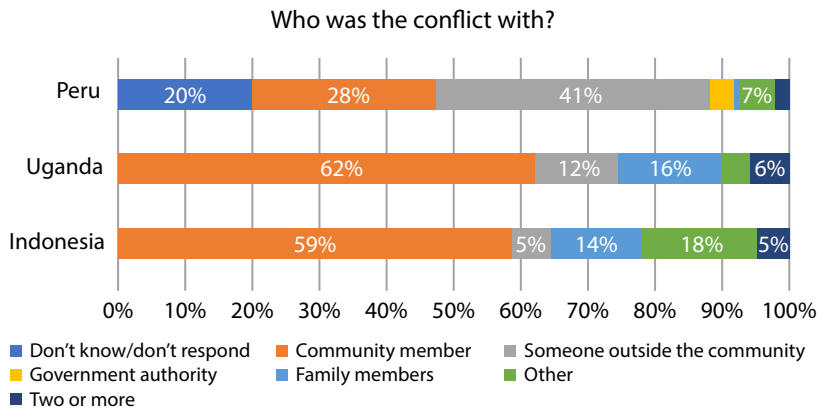

Figure 3. Villager reports on who the conflict was with

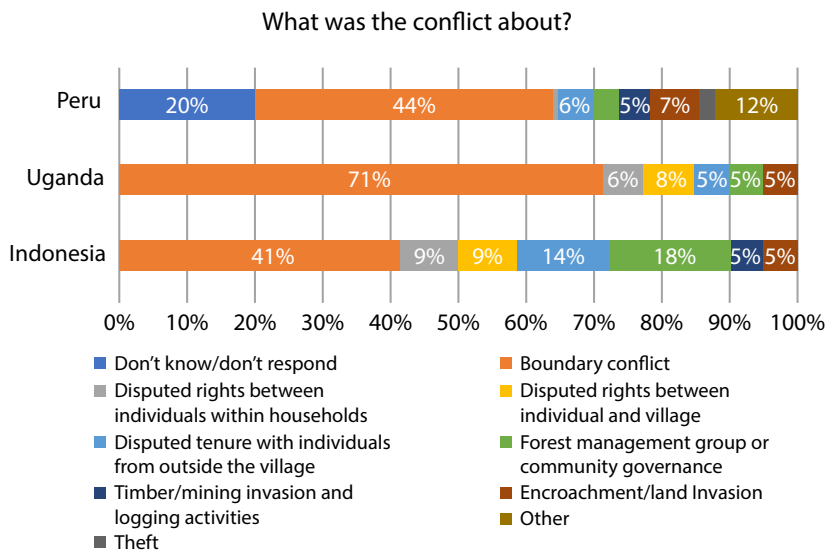

Figure 4. Villager reports on what the conflict was about

5 Forest management groups are more common in Nepal and Uganda, whereas "community" is more often the reference point in Peru. 


\section{Box 1. Community-level conflicts and tenure reforms}

Key informants and focus groups (FG) were asked to explain internal and external conflicts in their communities. In Indonesia, most FGs and key informants reported little conflict. Some mentioned specifically that the reform functioned as a conflict resolution mechanism, helping "illegal" communities to gain legal access to land. Only one key informant stated that the reform was a cause of conflict, because it did not meet community expectations. In FG discussions, conflicts with private companies were mentioned; these were not linked to the reform process.

In Uganda most key informants and FG participants did not mention reform as a cause of conflict, but did mention conflict with government authorities. Key informants reported conflicts with the government due to lack of assistance, conservation policy restrictions, suspicion about land-tenure rights (land/property being taken away) and corruption.

In Peru, in contrast, many key informants and FGs mention the reform itself as a cause of conflict. For example, in one village, a key informant noted that during the titling process, his village had to give up part of its ancestral territory. In other villages, key informants and FGs said that new, unclear boundaries were established (due to inadequate consultation procedures and overlaps) and that land was given to outsiders during titling. Some said internal problems were created because the titling procedure required the establishment of a community board of directors that was then involved in corrupt financial management. In both titled (reformed) and non-titled (non-reformed) communities, respondents reported problems with land encroachment by neighboring communities, illegal loggers, illegal miners and others.

an equal proportion (31\%) reported conflicts with external actors and with community members, and $25 \%$ declined to answer the question. Notably, titled villages have a higher portion of external conflicts (41\% compared to $31 \%$ ).

Villagers involved in conflict were also asked what the conflict was about (Figure 4). More than one response was permitted. The difference between countries was statistically significant $(p<0.005)$. The commonest response across all three countries was boundaries, with an overwhelming proportion providing this response in Uganda (71\%). The forest management group was the second most common source of conflict in Indonesia (notably, Indonesian government implementers did not mention this as a type of conflict they were called on to address). A variety of other responses was given, such as disputed rights (between individuals within households, between individuals and the village and between individuals and someone outside the village) or encroachment and land invasion. In the non-reformed villages in Peru, boundaries were also the commonest response. Conflicts within households and community governance tied for second place; these were not as important in the titled villages. (See also Box 1).

\section{Conflict resolution from the villagers' perspective}

The villagers involved in conflict in the past year were asked if the conflict had been resolved. The difference between countries is significant $(p<0.05)$, with almost all resolved $(91 \%, n=22)$ in Indonesia, $76 \%$ in Uganda $(n=50)$, but only $44 \%$ in Peru $(n=179)$, although the total number of conflicts was also much higher in Peru. Non-reformed villages also reported that $44 \%$ were resolved $(n=78)$.
Villagers were also asked who resolved the conflict (Figure 5). There were no significant differences between countries: internal community authorities, either elected or otherwise, solved the vast majority of conflicts. Elected authorities solved the majority in Uganda and Peru, whereas other village leaders resolved the highest proportion in Indonesia. In Peru and Indonesia, but not in Uganda, other local committees (cooperatives, conflict management committees) solved a large number. Government authorities solved a substantial number in Peru's untitled villages (29\%), but elected leaders there still solved 57\%. In Uganda, government solved 13\%. Court proceedings/litigation was only important in Uganda, for $8 \%$ of respondents (compared to $1 \%$ in Peru). This might be because the LCCs in Uganda make judicial procedures accessible for villagers, in comparison to the other countries.

These results demonstrate the importance of village-level conflict resolution mechanisms. However, given the high number of conflicts in Peru and the large proportion remaining unresolved, such mechanisms may be insufficient. This could be, in part, because a large portion of conflicts were, in fact, with actors external to the village.

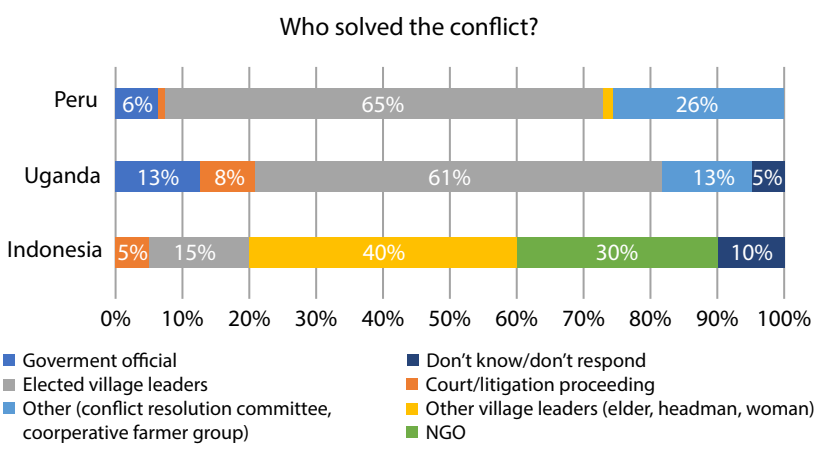

Figure 5. Villager reports on who resolved the conflict 


\section{Conflict resolution from the implementers' perspective}

The reform implementers responsible for managing conflict were also asked how effective the conflict resolution mechanisms were (Figure 6). In all countries, the majority of respondents stated that the mechanisms were effective (very effective/effective or somewhat effective). However, although Peru had the highest proportion stating they were very effective/ effective, a third said they were ineffective. This was also the highest among all countries studied.

\section{Discussion: Lessons for Peru}

Peru has the weakest legal framework for conflict management, with no clear mandate for government, particularly in titling native communities. Perhaps unsurprisingly, Peru has the lowest percentage of government officials stating that they have a responsibility for managing conflict and the highest percentage stating conflict resolution mechanisms are ineffective (although overall more are effective than not).

The lack of mandate raises concern in light of the villagelevel findings: Peru has the highe st percent of community members reporting conflicts during the past year, and the lowest percentage resolution. If the problem were internal to communities, this might suggest the need to reinforce community dispute resolution mechanisms. Nevertheless, Peru also has a very high portion (41\%) reporting conflicts with people external to their communities. Uganda appears to have the strongest alternative dispute mechanisms, although in practice, the results suggest that the villages studied in Uganda, Peru and Indonesia all rely heavily on local leaders and committees for conflict resolution.

Although a land title is the strongest form of legal tenure rights, the results show that titling alone is far from sufficient to address conflict. The comparison of outcomes in both titled and untitled communities in Peru reinforces this finding: the percentage of villagers in titled communities in conflict over the past year was more than twice that in untitled communities. Of more concern is that conflicts with external actors were higher in titled than untitled communities (41\% versus $31 \%$ ). This suggests that the legal definition of borders has not stopped encroachment. In fact, in Peru, villagers and village leaders described the titling process itself as a cause of conflict.

\section{What kinds of conflicts are we talking about?}

The definition of conflict was left open to the interpretation of the interviewees, eliciting different responses. Government officials implementing tenure reforms were asked what kinds of conflicts they were called on to manage or resolve, whereas male and female villagers were asked about specific land or forest conflicts they had been involved in during the previous year. In the context of collective reforms, the former has a clear

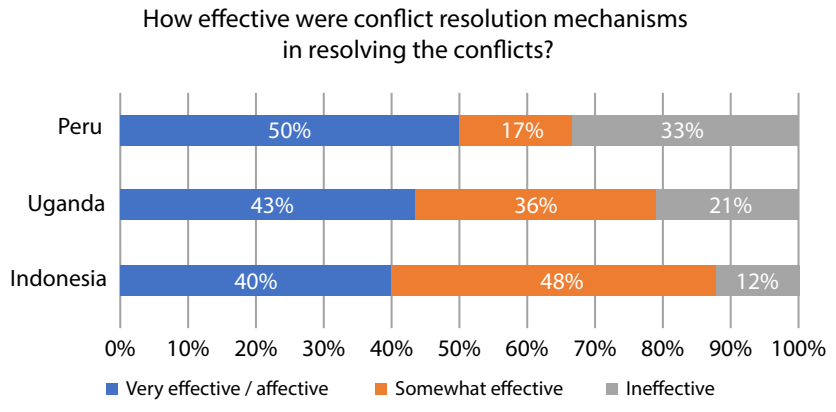

Figure 6. Government implementers' opinion on the effectiveness of conflict resolution mechanisms

community- or group-level focus, whereas the latter refers to the individual. Key informants and FGs were asked about community-level conflicts. Government officials' responses were based on their work and at country level, while the villages studied only represent a very small proportion of the total. The results were largely consistent for Indonesia and Uganda, but less so for Peru.

The commonest response from government and individual respondents in all three countries was that conflicts concerned boundaries. In Indonesia, the villages studied had very low levels of conflict overall, but boundaries were the commonest cause of conflict according to government and individuals; both also referred to conflicts with private companies. In Uganda, government respondents' top response referred to conflict with forest management groups, whereas, as if in response, key informants and FGs referred primarily to conflict with government authorities. Boundary conflicts were the main response of individuals and the second most important conflict mentioned by government.

Responses in Peru were more varied and provide insights regarding the nature of the problem and ways forward. First, all three types of respondents referred to boundaries as a problem, but this was quite low on the list for government. This illustrates that government is rarely called to address the most important problem facing individuals. This would be appropriate if boundary conflicts were among individuals within a titled community; as noted previously, the results suggest they are not.

Second, government officials reported the most important "conflict" was the weaknesses of government itself (e.g. personnel, communication, budget), followed by community governance, then law enforcement. The first and third of these refer to government weaknesses (two topics barely mentioned in the other countries).

Third, like government implementers, village FGs and informants also referred to problems with community governance, but for them, this was directly associated with the titling process. Some argued that new community leadership bodies led to corruption (in other communities, however, people spoke 
highly of governing bodies, for example, in reducing conflicts with external settlers). The titling process was also blamed for territory loss and for blurring, rather than clarifying, boundaries. Among other things, these responses demonstrate mutual distrust between communities and government.

Fourth, encroachment of various forms by outsiders were key problems for individuals and villages but were not mentioned by government implementers as problems. While some of these conflicts may be what government referred to under law enforcement, the large differences suggest further disconnect between indigenous community needs and the government mandate to support solutions.

\section{Who should resolve (which) conflicts?}

The right mechanisms and approaches are needed for conflict management and transformation, based on the nature of the conflict in question. Ideally, indigenous communities should solve their own problems whenever possible. But not all conflicts related to land or forest tenure are internal to communities; some external conflicts require support beyond the community level for resolution. This is particularly true if the conflict in question is related to the defense of the community's property right.

By definition, a property title is given meaning precisely because it is backed by the state that issues it. Problems with boundaries between communities, encroachment by neighbors or theft of community resources by outsiders are all in the purview of the state. This does not mean that state intervention is required in every case but rather that it is the responsibility of the state to establish the institutions to defend and protect the titles issued, as well as the rights of the country's indigenous citizens. This includes establishing accessible and inclusive mechanisms for conflict resolution and transformation.

\section{Government and conflict management in Peru}

Problems with internal coordination and overlapping government functions can cause confusion and aggravate conflict (Baranyi and Weitzner 2006; Herrera and Guglielma da Passano 2006). In Peru, Huamaní et al. (2012) have argued that conflict management institutions particularly suffer from this disarticulation, and that there is a shortage of government specialists to manage conflict. A government report found that the inadequate response of public entities was one of the main causes of conflicts in the Amazon region (PCM, 2018), and scholars in Peru agree that the high level of conflict is due in large part to the low institutional capacity for conflict management (Tanaka 2011; Huamaní et al. 2012; Orihuela and Paredes 2017).

Peru has developed a conflict management system to address problems with extractive industries and socio-environmental regulation (Huamani et al. 2012). However, the system is disorganized and focused on crisis, a possible sign of deeper problems. Merino (2015) argues that conflict in Peru is a matter of divergent political ontologies, where the state views the Amazon as a place for natural resource exploitation, while ignoring other interactions with the environment. A new holistic legal framework is needed, with an intercultural approach that includes indigenous perspectives.

\section{Conclusions and recommendations}

This research demonstrates that titles alone are insufficient for the defense of territory: the delivery of a title is not "the end" of the process of securing indigenous community rights. ${ }^{6}$ Nor is the government absolved of responsibility once the title is granted.

As noted by the Voluntary Guidelines on the Responsible Governance of Tenure of Land, Fisheries and Forest (VGGT), landtenure disputes need accessible and effective access to justice and conflict resolution mechanisms. The state is also responsible for protecting the indigenous population in any transaction with private parties and supporting capacity development so that any consultation process is carried out appropriately. This needs to be combined with the fight against corruption.

In Uganda, conflict management institutions highlight the importance of engaging local authorities in formal conflict resolution systems. Baranyi and Weitzner (2006) note that capacity building is needed for all parties to facilitate resolution of land-related conflicts.

In summary, legal frameworks for conflict management need to recognize local/customary authorities in dispute resolution processes, to establish clear procedures for land-tenure/forest conflicts and to establish clear mandates for government officials on conflict resolution. Conflict needs to be addressed not only during the formalization process but also after formalization is completed.

\section{Acknowledgements}

CIFOR's 'Global Comparative Study on Forest Tenure Reform' is funded by the European Commission and the Global Environmental Facility (GEF) with technical support from the International Fund for Agricultural Development (IFAD) and the United Nations Organization for Food and Agriculture (FAO). We would also like to thank Safia Aggarwal, Peter Veit, Alain Frechette and Sondra Wentzel for their helpful reviews and comments and Karin Rivera for her support on the statistical analysis. This study forms part of the Program on Policies, Institutions and Markets (PIM), led by the International Food Policy Research Institute (IFPRI); and the CGIAR Research Program on Forest, Trees and Agroforestry (FTA), led by CIFOR. The opinions expressed in this paper represent the analysis of the authors and do not necessarily reflect the views of CIFOR, CGIAR or the financial sponsors.

6 Or securing livelihoods, which also deserves the support of the state. 


\section{References}

Ardiansyah, F., Marthen, A.A. and Amalia, N. 2015. Forest and Land-use Governance in a Decentralized Indonesia: A Legal and Policy Review. Occasional Paper No. 132. Bogor, Indonesia: CIFOR.

Baranyi, S. and Weitzner, V. 2006. Transforming Land-related Conflict: Policy, Practice and Possibilities. Ottawa and Rome: North-South Institute.

Coldham, S. 2000. Land reform and customary rights: the case of Uganda. Journal of African Law 1: 65-77.

Fitzpatrick, D. 2005. 'Best practice' options for the legal recognition of customary tenure. Development \& Change 36(3): 449-475.

Gautam, A. Shivakoti, G. and Webb, E. 2004. A review of forest policies, institutions, and changes in the resource condition in Nepal. The International Forestry Review 2(6): 136-148.

Heinen, J. and Mehta, J.N. 2000. Emerging issues in legal and procedural aspects of buffer zone management with case studies from Nepal. The Journal of Environment \& Development 9: 45-67.

Herrera, A. and Guglielma da Passano, M. 2006. Land Tenure Alternative Conflict Management. Rome: FAO.

Huamaní, G., Macassi, S., Alegría, J., and Rojas, T.2012. Hacia una mejor gestión de los conflictos socioambientales en el Perú. Lima: Consorcio de Investigación Económica y Social.

Merino, R. 2015. The politics of extractive governance: Indigenous peoples and socio-environmental conflicts. The Extractive Industries and Society 1 (2): 85-92.
Orihuela, J. and Paredes, M. 2017. Fragmented layering: building a green state for mining in Peru. In Dargent, E., Orihuela, J., Paredes, M., and Ulfe, M. (eds.) Re source Booms and Institutional Pathways. Cham: Palgrave Macmillan.

Presidencia del Consejo de Ministros de la República del Perú (PCM). 2018. Reporte mensual agosto 2018. Revista Willaqniki, no. 4. Lima, Peru: PCM.

Shrestha, K.B. 1998. Community Forestry and Conflicts in Nepal. In FAO, Integrating conflict management considerations into national policy frameworks: Proceedings, Antalya, Turkey, Oct. 10-13, 1997 (pp. 283-290). Rome: FAO.

Tanaka, M. 2011 ¿Por qué el Estado no responde adecuadamente a los conflictos sociales? Y ¿qué hacer al respecto? Lima, Peru: IEP (Instituto de Estudios Peruanos), CIES (Consorcio de Investigación Económica y Social).

Rights and Resources Initiative (RRI). 2017. Power and Potential: A Comparative Analysis of National Laws and Regulations Concerning Women's Rights to Community Forests. Washington, DC: RRI.

Rights and Resources Initiative (RRI). 2018. At a Crossroads. Consequential trends in recognition of community-based forest tenure from 2002-2017. Washington, DC: RRI.

Obaikol, E. 2014. Draft Final Report of the Implementation of The Land Governance Assessment Framework in Uganda. Washington, D,C: World Bank Group.

Yasmi, Y., Anshari, G., Komarudin, H., and Alqardi, S. 2016. Forest tenure policies in Nepal: Status, gaps and way forward. Rome: FAO Regional Office for Asia and the Pacific.

\begin{tabular}{|c|c|c|}
\hline \multirow[t]{2}{*}{ CGIAR } & $\begin{array}{l}\text { RESEARCH } \\
\text { PROGRAM ON } \\
\text { Policies, } \\
\text { Institutions, } \\
\text { and Markets }\end{array}$ & \multirow[t]{2}{*}{$\begin{array}{l}\text { The CGIAR Research Program on Policies, Institutions, and Markets (PIM) leads action-oriented research } \\
\text { to equip decisionmakers with the evidence required to develop food and agricultural policies that better } \\
\text { serve the interests of poor producers and consumers, both men and women. PIM combines the resources } \\
\text { of CGIAR centers and numerous international, regional, and national partners. The program is led by the } \\
\text { International Food Policy Research Institute (IFPRI). www.pim.cgiar.org }\end{array}$} \\
\hline & & \\
\hline
\end{tabular}

\begin{tabular}{|c|c|c|}
\hline \multirow[t]{2}{*}{ CGIAR } & \multirow[t]{2}{*}{$\begin{array}{l}\text { RESEARCH } \\
\text { PROGRAM ON } \\
\text { Forests, Trees and } \\
\text { Agroforestry }\end{array}$} & $\begin{array}{l}\text { The CGIAR Research Program on Forests, Trees and Agroforestry (FTA) is the world's largest research } \\
\text { for development program to enhance the role of forests, trees and agroforestry in sustainable } \\
\text { development and food security and to address climate change. CIFOR leads FTA in partnership with } \\
\text { Bioversity International, CATIE, CIRAD, ICRAF, INBAR and TBI. }\end{array}$ \\
\hline & & FTA's research is supported by CGIAR Fund Donors: cgiar.org/funders/ \\
\hline
\end{tabular}
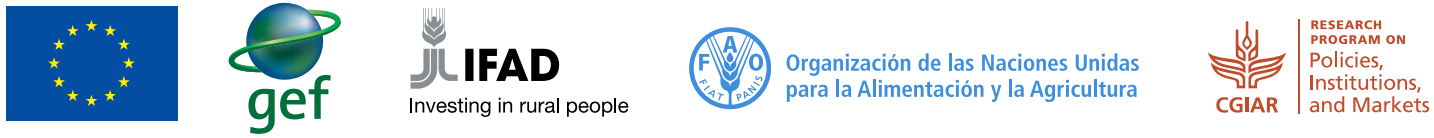